\title{
Ibn Khaldun: Managing Justice in Economy
}

\author{
Moch. Bukhori Muslim \\ Syarif Hidayatullah \\ State Islamic University Jakarta, Indonesia \\ bukhori.muslim@uinjkt.ac.id
}

\begin{abstract}
This study aims to discuss economic issues in Ibn Khaldun's perspective. The method used in this research is descriptive analytical, with the main data source from Ibn Khaldun's book, Muqaddimah. The findings of this research are Ibn Khaldun states that the economic activities of society become the benchmarks of people's welfare. The government should organize and direct the economy of society fairly, so that the people work hard and try to grow the economy. The implication is that the government must create a stimulus to encourage all elements of society to have a positive impact on the economy. As a result, the government will accumulate wealth for the country from the community.
\end{abstract}

Keywords_Justice; Fiscal; Government;

\section{INTRODUCTION}

A long economic depression has occurred since 1873 until the late 1890s and is believed to have been triggered by various factors, including the second Industrial Revolution which resulted in an increase in production unmatched by the rise in demand levels.[2] The fall of Wall Street in the US in 1930, causing the depression of the world economy. [3] High import duty tax policy had been responded by raising higher taxes by other countries. Many were unemployed and people's purchasing power decreased.(Galbraith, 1929, Beasley, 2003) Japan was affected by world depression. Mass strikes in towns and peasant resistance across the village happened. Millions of people were unemployed and aagricultural products were not enough to meet the needs.(Beasley, 200) Germany which was built on American borrowing funds was also affected by the economic crisis in America. Industry stopped working, production fell, workers were fired created highunemployment, inflation, as well as rare and expensive goods.[4] Countries in Southeast Asia were also experiencing economic crisis that suffered people.(Furnivall, 1944)

The problems of the economic justice, is always be a hot topic. This article discusses how Ibn Khaldun, in Muqaddimah, explains economic justice. Ibn Khaldun states that the management of economic justice by the state determines the welfare of society. Discussing the prosperity of a country is determined by the least economic activity undertaken by the community. Ibn Khaldun stated that the government should encourage people to "build the economy not in an individualistic way but as a community.( Khaldun, 1993)

\section{GOVERNMENT AND ECONOMIC SUPERVISION}

John Maynard Keynes argues that economic depression can be overcomed by granting authority to governments in the supervision of the economy. The idea is the antithesis of a free market support group often referred to as laissez-faire which means liberated.(Skidelsky, 2008) The classical theory states that economic freedom is a human right for every person to do whatever he wants without goverment intervention.(Reinert, 1999)

Ibn Khaldun argues that the state is the ruler of the market (al-suq al-a'zham). The government should be able to provide basic needs for the people, but the price should not be set by the government. Ibn Khaldun says that in a city which population grows rapidly, the government's priority is to provide basic needs, so that there will be an increase in supply resulting in falling prices of basic commodities. In contrast to luxury goods, lifestyle changes people in the city, leads to increase in the demand of luxury goods, the prices of these goods will rise. (Khaldun, 1993) The market equilibrium mechanism is determined by the supply and demand mechanism. Ibn Khaldun said that trade by the authorities would have a negative impact on state revenues. [6] Government is a regulator in economic activity and not a rival to society. Government direct involvement in business will results a decrease in people willingness to invest. Economic activity will slow down and there is no more tax object for the authorities (Khaldun, 1993). [7] Ibn Khaldun explains that the factors that cause the price of goods to rise is high production costs, resulting from expensive customs tariffs, taxes and other fees charged by the government, (Khaldun, 1993) oarding, expensive transportation costs and security costs. (Khaldun, 1993) Ibn Khaldun explains that the negative impact of the low price is the decrease in producer's motivation to produce. Conversely, high prices lead to a lack of consumer interest to buy, and the market will depreciate. A reasonable profit will encourage increased trade. [8]

Ibn Khaldun refuses pricing by the ruler, but demanded the creation of a fair price. Both the seller's and buyer's interests must be protected. It rests on the hadith which states the Messenger of Allah response to someone's request for controlling price. [9] The Hadith is understood as the basis for 
the ruler to control the market instead of freeing the market. Control of the market is not by controlling the price of goods. [10] The government is the market regulator, which regulates the policy in case of instability in the market. (Irijanto, 2013)

\section{FISCAL IN ECONOMIC STABILITY}

Ibn Khaldun formulates tax theory. Ibn Khaldun's tax theory was developed by Keynes in terms of aggregate effective demand, multiplier effects and equality of income and expenditure. Umer Chapra states that Keynes was the successor of Ibn Khaldun.(Chapra, 2000) Ibn Khaldun states that tax is a major component of public finance whereeconomic development depends on the structure of taxation and the management of state finances.

Ibn Khaldun asserted that the goverment should not be a trader and should not be close to the merchant. Ibn Khaldun disagreed if the government went directly into business to gain profits to cover the lack of tax revenue. If the government trades, its people will be less competitive so there will be no more trade and agriculture by the community. As a result, there is no taxable object that can be collected. If the government joined the trade, it will not pay taxes. Ibn Khaldun also criticized the government that close to businessman since the relationship may create unfair tax levies. [5]

Ibn Khaldun explained that the management of state finances must be conducted properly. Monitoring the use of funds must be strictly enforced to avoid budget misuse. Government budgeting should prioritize public needs. The state budget is not for spree, including the purchase of luxury goods for the needs of officials, as it will spend the budget.( Chapra, 2000) [11]

The role of the ruler is to provide economic stimulus that impacts on increasing tax revenue. The government should encourage people to work hard by providing extensive employment. Ibn Khaldun stated that the ruler is the main and largest market for the people. Government should be the main source of money. The government is the creator of money to run the economy.

The government must issue a budget to create a business field that will eventually collect taxes from economic activities created. Market lethargy is caused by the absence of government spending. Ibn Khaldun asserted that wealth must be rotated between people and rulers.

Keynes's thoughts about low taxes and increased spending by the government for economic improvement are in common with Ibn Khaldun's findings. Keynes proposed a settlement of economic downturn by cutting tax rates and increasing state spending. Keynes believes that by having fiscal expansion will create multiplier effect on aggregate demand and output. Fiscal expansion will increase aggregate demand through one of two paths. First, if the ruler increases spending and fixed tax revenues, then aggregate demand will directly increase. Second, if the authorities cut tax revenue or increase transfer payments, then disposable income can increase, so people tend to increase consumption.
Ibn Khaldun asserted that the cause of inflation or the rise in the value of the currency marked by the increase in the price of needs is due to natural factors and human activities of ihtikar (hoard). Ibn Khaldun mentions three kinds of human needs for goods, namely primary goods, secondary and tertiary.[12] Three kinds of goods have different characteristics in the period of inflation. The price of basic needs will increase during natural disasters and hoarding. Secondary goods will rise in price, when public welfare improves. Tertiary goods are experiencing a price increase due to 3 factors: First, demand is very high due to excess wealth the middle-class have. Second, the middle-class sense of pride because of their ability to fullfil basic needs. Third, the middle-class desire to show off to others.

Ibn Khaldun asserted that continuously increased price causes the food supply to decrease. Ibn Khaldun mentions some evidences by showing a fertile country with many natural resources but having very expensive goods. Meanwhile, there were other countries with minimal natural resources but having cheap price of goods.

Unemployment is defined by Ibn Khaldun as inqibad alyad 'a al-i'timarie: hand shackled. Unlike conventional thinkers who consider unemployment as a forced condition because the state is unable to provide jobs, Ibn Khaldun stressed that unemployment can be solution for empowering people to be more creative than government efforts to provide jobs.

\section{CONCLUSION}

Ibn Khaldun states that the prosperity of a country is determined by the quantity of economic activity carried out by the community. Natural resources will be meaningless without human work activities. Countries with abundant natural resources do not automatically make their people prosperous. Community economic activity plays an important role to increase income. The unemployment rate will result in a decrease in the level of prosperity. Ibn Khaldun states that economic growth and prosperity is characterized by an expansion in markets with various economic activities. Government interference is necessary to regulate and direct the economy. Economic growth is determined by the large number of people's economic activities. The ruler must encourage all elements of society to have active role in economic activity. The result is that the rulers will accumulate state wealth from tax collection.

\section{REFERENCES}

[1] Ibn Khaldun was born in Tunis on Ramadan 1st 731 A.H (27th May, 1332 C.E. and died in Cairo in 1406. see Sule Ahmed Gasau, 'Economic Thoughts Of Ibn Khaldun', Journal of Islamic Economics, Vol. 3, No. 1, January 1993. P. 61-80 and Adil H. Mouhammed, 'On Ibn Khaldun's Countribution to Heterodox Political Economy, Academic Journal Article, History of Economics Review. https://www.questia.com/read/1G1-227598648/on-ibn-khaldun-scontribution-to-heterodox-political. Ibn Khaldun is recognized as the 
foundation of modern economic political theory. Adil H. Mouhammed, "On Ibn Khaldun's Contibution to Keterodox Political Economy". History of Economics Riview, No. 46, Summer 2007: p. 89-105. See more Jean David Boulakia, Ibn Khaldun: A Fourteenth Century Economist, (Journal of Political Economy, vol 79, No. 5 Sep/0ct. 1971, p. 1105-1118. See Choirul Huda, 'Pemikiran Ekonomi Bapak Ekonomi Islam; Ibn Khaldun', Economica: Jurnal Ekonomi Islam, p-ISSN: $2085-$ 9325/e-ISSN: 2541-4666, Vol. IV/Edisi 1/Mei 2013, p. 103-125.

[2] Int. Journal of Management Economics and Business, Vol. 8, No. 16, 2012. COMPARISONS BETWEEN THE LONG DEPRESSION, THE GREAT DEPRESSION and THE GLOBAL FINANCIAL CRISIS, Yrd.Doç.Dr. Selçuk BALI Ordu Üniversitesi MYO, Muhasebe ve Vergi Bölümü.

[3] Mencari Akar Masalah Krisis Finansial Global, Zarah Puspitaningtyas, Universitas https://www.researchgate.net/publication/259309697. Diakses 28 Nopember 2017

[4] The Crash 1929 (htt://www.pbs.org/wgbh/amex/crash/timeline/timline2.html. Diakses tanggal 1 Maret 2016.

[5] In terms of the relation of the ruler as well as being a businessman, has been strongly criticized by cabinet ministers President Joko Widodo and Yusuf Kalla. Rizal Ramli as Coordinating Minister of Maritime and Resources, stated that the rulers who become entrepreneurs will be a disaster for the people of Indonesia. Even he also stated that it includes betraying democracy. http://www .republika.co.id/berita/nasional/politik/16/01/12/o0tjex365rizal-ramli-penguasa-sekaligus-pengusaha-malapetaka-untuk-rakyat. diakses tanggal 26 Februari 2016.

[6] Ibn Khaldun wrote a special chapter on negative influences if a country's ruler joined the trade. Ibn Khaldun makes chapter title:

$$
\text { الفصل الأربعون: في أن التجارة من السلطان مضرة بالر عايا مفسدة للجباية. }
$$

[7] The price mechanism initiated by Ibn Khaldun is $\mathrm{n}$ poured in a special chapter entitled Fi 'as'ar al-mudun (prices in the city)

[8] This interpretation is also stated by Charles Issawi. Charles Issawi, Ibnu Khaldun'S Analysis of Economics Issues dalam Abdul Hasan M. Shadeq dan Aidit Ghazali (ed), Reading in Islamic Thought (Malaysia: Logman, 1992), p. 224

[9] In a hadith narrated by many narrators of hadith, which reads as follows: Meaning: "People complain, 'O Messenger of Allah, the price (at that time) rises, so than that set the price for kammi'. Messenger of Allah. said: 'Allah is the determinant of the price, the Greatest, the Great and the All-Rizler. Indeed I hope to be able to face your Allah without any tyranny that you claim to me in matters relating to blood and property. "This Hadith is narrated by some narrators. Abu Dawud, Sunan Abi Dawud (Beirut: Dar al-Kutub al-'Ilmiyah, tt), jilid 3, p. 286. Ibn Majah, Sunan Ibnu Majah (Beirut: Dar al-Fikr, tt), jld 2, p. 741. Imam Baihaqi, Sunan al-Baihaqi al-Kubra (Beirut: Maktabah Dar al-Kutub al-'Ilmiyah, tt), jld 6, p., 29. Abu Ya'la, Sunan Abi Ya'la (Beirut: Dar al-Ma'mun, tt), jld. 6, p., 444.

[10] The scholars differed in terms of price fixing by the government. Imam Ibn Quddamah al-Maqdisi states that the government has no right to regulate prices. Entrepreneurs are allowed to sell goods at the price they want. He mentions that from Madzhab Shafi'i also argue the same (the government is not entitled to set the price in the market). Ibn Quddamah gives two reasons, first: because the Messenger of Allah. do not even forbid it. Second, pricing is an unlawful injustice. Ibn Quddamah, alMughni (Beirut: Dar al-Fikr, 1980), juz 8, p. 401. Whereas Mad\} hab Maliki allows the ruler to fix the price if it is necessary for the benefit of the people. This is based on the opinion of Imam al-Laith stating that the ruler may set the price for the benefit of the people. Ibn 'Abd al-Bar, alIstidzkar (Beirut: Dar al-Kutub al-'Ilmiyah, 2000), juz 6, p. 412. Al-'Azi $\mathrm{m}$ Abain also quotes the opinion of Malik about the permission of the ruler to fix the price. Al-'Azim Abadi, 'Aun al-Ma'bud Sharh Sunan Abi Dawud (Beirut: Dar al-Kutub al-'Ilmiyah, 1415 H), Juz 9, p. 230. AlMubarakfuri explains the content of the hadith about tas'ir, that if the ruler only protects the interests of one party ie the buyer only by fixing the price, it will be contrary to the word of Allah swt. that the sale and purchase must be based on equally rido. Al-Mubarakfuri, Tuh'fah alAhwadhi (Beirut: Dar al-Kutub al-'Ilmiyah, 2000), Juz 4. P. 452. It is understood that the meaning of the above hadith does not imply a ban on tas'ir for the ruler but indicates the ruler's role to control the market. The Hadith can be understood by explanation:

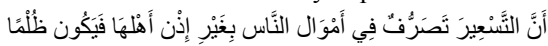

So the ruler may set the price for the benefit of the people. Al-Mula 'Ala al-Qari, Mirqah al-Mafatih\} Sharh\} Mishkah al-Mashabih\} (Beirut: Dar al-Kutub al-'Ilmiyah, 1999), juz 2, p. 320.

[11] Included in the budget waste such as the purchase of luxury cars for officials and procurement of goods and services excessive. Current government of Indonesia reported that the President of RI often make budget cuts that are considered waste of the state budget, like buying a car that has very expensive service and others. http://bisniskeuangan.kompas.com/read/2014/09/10/074121326/Ini.Sum ber-sumber.Pemborosan.di.RAPBN.2015. Ibn Khaldun, Muqaddimah, p. 221-223.

[12] Primary goods include staple foods, such as wheat, grains, onions, chili, and other cooking spices. The secondary goods include meat, fruits etc. Tertiary goods include private vehicles etc. Lihat Ibn Khaldu $>\mathrm{n}$, Muqaddimah, p. 286.

[13] 'Abdu al-Mahdi, 'Adil. Al-Thawabit wa al-Mutaghayyirat fi al-Tarikh al-Iqtishaq li al-Bilad al-Islamiyyah. Baghdad: Markaz Dirasaat Falsafat al-Din, al-Dar al-'Arabiyah li al-'Ulum Nashirun, 2009.

[14] Abadi, Al-'Azim. 'Aun al-Ma'bud Sharh Sunan Abi Dawud. Beirut: Dar al-Kutub al-'Ilmiyah. $1415 \mathrm{H}$.

[15] Abu Dawud, Sunan Abi Dawud. Beirut: Dar al-Kutub al-'Ilmiyah, tt.

[16] Abu Ya'la, Sunan Abi Ya'la. Beirut: Dar al-Ma'mun, tt.

[17] Al-Mubarakfuri. Tuhfah al-Ahwadhi. Beirut: Dar al-Kutub al-'Ilmiyah, 2000.

[18] Beasley,W.G. Pengalaman Jepang: Sejarah Singkat Jepang, translator Masri Maris. Jakarta: Yayasan Obor Indonesia, 2003.

[19] Boulakia, Jean David. Ibn Khaldun: A Fourteenth Century Economist. Journal of Political Economy, vol 79, No. 5 Sep/0ct. 1971, p. 1105 1118.

[20] Galbraith, John Kenneth. The Great Crash 1929. Boston: Houghton Mifflin, 1954.

[21] Gasau, Sule Ahmed. 'Economic Thoughts Of Ibn Khaldun', Journal of Islamic Economics, Vol. 3, No. 1, January 1993. P. 61-80.

[22] Huda, Choirul. 'Pemikiran Ekonomi Bapak Ekonomi Islam; Ibn Khaldun', Economica: Jurnal Ekonomi Islam, p-ISSN: 2085-9325/eISSN: 2541-4666, Vol. IV/Edisi 1/Mei 2013, p. 103-125

[23] Ibn 'Abd al-Bar. al-Istidzkar. Beirut: Dar al-Kutub al-'Ilmiyah, 2000.

[24] Ibn 'Asakir. Tarikh Madinah Dimashq. Beirut: Dar al-Fikr, tt.

[25] Ibn Khaldun, Muqaddimah. Beirut: Dar al-Kutub al-'Ilmiyah, 1993.

[26] Ibn Majah, Sunan Ibnu Majah. Beirut: Dar al-Fikr, tt.

[27] Ibn Quddamah. al-Mughni. Beirut: Dar al-Fikr, 1980.

[28] Imam Baihaqi, Sunan al-Baihaqi al-Kubra. Beirut: Maktabah Dar alKutub al-'Ilmiyah, tt.

[29] Int. Journal of Management Economics and Business, Vol. 8, No. 16, 2012. COMPARISONS BETWEEN THE LONG DEPRESSION, THE GREAT DEPRESSION and THE GLOBAL FINANCIAL CRISIS, Yrd.Doç.Dr. Selçuk BALI Ordu Üniversitesi MYO, Muhasebe ve Vergi Bölümü.

[30] Irijanto, Tubagus Thresna.Mohd. Azlan Shah Zaidi dan Abdul Ghafar Ismail. 'The Thought of Economic Growth Theories of Classical Muslim Scholars, A Contribution, Journal Trikonomika, Volume 12, No. 2, Desember 2013, pp. 168-189, ISSN 1411-514X

[31] Issawi, Charles. Ibnu Khaldun'S Analysis of Economics Issues dalam Abdul Hasan M. Shadeq dan Aidit Ghazali (ed), Reading in Islamic Thought, Malaysia: Logman, 1992.

[32] J.S., Furnivall. Nethrelands India: A Study of Plural Economy. Cambridge: The University Press, 1944.

[33] Kale, Sumita. 'A Global Keynesian Revival'. www.livemint.com.

[34] M. Umer Chapra. The Future of Economics: A Islamic Perspective. Leicester, UK: The Islamic Foundations, 2000.

[35] McElvaine, Robert S. The Great Depression: Amerika, 1929-1941. New York: Times Book, 1993. 
[36] Mencari Akar Masalah Krisis Finansial Global, Zarah Puspitaningtyas, Universitas https://www.researchgate.net/publication/259309697. Diakses 28 Nopember 2016.

[37] Mouhammed, Adil H. 'On Ibn Khaldun's Countribution to Heterodox Political Economy, Acacdemic Journal Article, History of Economics Review. https://www.questia.com/read/1G1 227598648/on-ibn-khaldun-s-contribution-to-heterodoxpolitical.

[38] Mouhammed, Adil H. “On Ibn Khaldun's Contibution to Keterodox Political Economy”. History of Economics Riview, No. 46, Summer 2007: p. 89-105.

[39] Murtadho. Ali. 'Kajian Pengangguran Dalam Perspektif Pemikiran Ibn Khaldun', disertasi UIN Syaraif Hidayatullah Jakarta, 2010.

[40] P. Usher, Abbot et.al. "Economic History-The Decline of Laissez Faire”, American Economic Review 22 (1 supplement, 1931.

[41] Reddy, Sudeep. "The New Old Big Thing in Economics: J.M. Keynes". The Walla Street Journal, 08-01-2009). http://www.wsj.com/articles/revesion-notes/a2-macrophillips-cueve.html.
[42] Reinert, Erik S. 'The Role of The State in Economic Gowth'. Journal of Economic Studies. Vol. 26, No. 4/5, 1999, pp. 268-326, MCB University Press, 0144-3585.

[43] Roubini, Nouriel. 'Current Account and Budget Deficit In An International Model of Cunsumption and Taxation Smoothing A Solution to The 'Feldstien-Horioka Puzzle?' Working Paper No. 2773 National Bureau of Economic Reserch 1050 Massachusetts Avenue Cambridge, MA 02138 November 1988.

[44] Skidelsky, Robert dan Robert Jacob Alexander Skidelsky. John Maynard Keynes, 1883-1946: Economist, Philosopher, Statesmen. UK: Penguin Books, 2008.

[45] Smith, Adam. The Wealth Nations. New York: Modern Library, 1965.

[46] Suparmoko, M. Keuangan Negara Dalam Teori dan Praktek. Yogyakarta: Penerbit BPFE, 2000.

[47] The

$$
\text { Crash }
$$

of

1929 ,

htt://www.pbs.org/wgbh/amex/crash/timeline/timline2.html. Diakses tanggal 1 Maret 2016.

[48] Viner, Jacob. 'Mr. Keynes on The Causes of Unemployment', Oxford Universicity Press: The Quarterly Journal of Economics, Vol. 51, No. 1 (nov., 1936), pp. 147-167. http://www.jstor.org/stable/1882505. 